\title{
Pengaruh Lama Stimulasi Listrik Dan Jenis Otot Terhadap Kandungan Air, pH Dan Cooking Loss Daging Sapi Pesisir
}

\author{
Hilda Susanty dan Arnim \\ Fakultas Peternakan Universitas Andalas Padang
}

\begin{abstract}
The aims of the present research were to study the effect of time periods of electrics stimulation and muscle type on water content, $\mathrm{pH}$ and cooking loss of meat of pesisir cattle. This research was designed according to factorial attempt pattern $3 \times 3$ based on Randomized Block Design (RBD). The treatments were 3 levels of electric stimulated time, i.e. $A 1=1$ minute, $A 2=2$ minutes and $A 3=3$ minutes as $A$ factor, for the $B$ factor is the muscle they are $B 1=$ Longisimus dorsi, B2=S Supra spinatus and $B 3=B i c e p$ femoris. Results showed that water content of meat pesisir cattle ranged from $78.17-77.41 \%, \mathrm{pH}$ 6.03- 5.70 and cooking loss ranged from 42.31 - 37.96. The electric stimulated didn't give significant effect $(P>0.05)$ on water content and $\mathrm{pH}$, but cooking loss percentage decreased significantly $(P<0.05)$ by increasing the time periods of electric stimulation time. Muscle type gave significant effect $(P<0.05)$ on cooking loss.
\end{abstract}

Key word : meat processing, pesisir cattle

\section{Pendahuluan}

Permintaan daging untuk
konsumsi dalam negeri terus meningkat dari tahun ke tahun, tetapi belum dapat diimbangi oleh peningkatan produktivitas ternak penghasil daging. Selain itu pertumbuhan penduduk, peningkatan pendapatan, kesadaran pangan dan gizi masyarakat, meningkatnya arus wisatawan luar ke Indonesia serta peluang ekspor ke beberapa negara di kawasan Asia Pasifik (Korea Selatan, Thailand, Taiwan, Hongkong dan Singapura) merupakan peluang baru dalam usaha peternakan, khususnya peternakan sapi pedaging yang berkualitas tinggi (Gurnadi, 1993).

Impor daging berkualitas untuk memenuhi permintaan pasar di supermarket, hotel herbintang dan restoran internasional setiap tahunnya juga meningkat, sedangkan daging sapi produksi dalam negeri (sapi lokal) kualitasnya belum memenuhi standar persyaratan. Produksi daging sapi lokal khususnya sapi Pesisir umumnya untuk memenuhi permintaan pasar lokal. Selain itu juga harga jual yang diterima oleh peternak lokal masih relatif rendah, tidak sebanding dengan biaya, waktu dan tenaga yang dikeluarkan. Secara kuantitatif, meskipun pangsa pasarnya terbesar, tetapi manfaatnya bagi peternak rakyat belum nyata. Permasalahannya adalah bagaimana meningkatkan kualitas daging sapi lokal, sehingga peternak sapi lokal dapat menerima tingkat harga jual yang layak.

Untuk tujuan ini, metode produksi ternak perlu diarahkan kepada peningkatan kualitas daging sesuai dengan kriteria persyaratan pasar internasional. Usaha ini dapat 
pula mengakibatkan penghematan devisa negara jika hasilnya dipergunakan untuk mensubstitusi daging berkualitas tinggi yang selama ini diimpor.

Bagaimanapun baiknya mutu dan kondisi sapi potongan, jika penanganan sebelum dipotong, pada waktu dipotong dan sesudah pemotongan kurang memadai maka daging yang dihasilkan tidak akan memenuhi standar mutu yang baik. Pada penanganan sesudah pemotongan (pasca panen) untuk memperbaiki kualitas daging perlu dilakukan penggunaan teknologi stimulasi listrik pada potongan karkas. Stimulasi listrik dilaksanakan dengan memberikan ransangan listrik terhadap daging setelah dilaksanakan pemotongan. Stimulasi listrik juga dapat dilakukan terhadap karkas, yang mana dengan adanya stimulasi listrik proses rigormortis atau pelayuan terhadap daging atau karkas bisa lebih dipercepat, sehingga kita tidak perlu menunggu waktu rigormortis beberapa jam agar dapat melakukan pemotongan terhadap karkas. Menurut Bouton et al. (1978) stimulasi listrik mempunyai beberapa keuntungan; (1) hanya memerlukan sedikit modifikasi di dalam praktek abatoir, dan (2) pemisahan daging dari karkas prerigor yang disebut hotboning dapat dilakukan terhadap karkas secara utuh, belahan karkas atau potonganpotongan karkas. Selanjutnya dilaporkan pula oleh McKeit et al. (1980), bahwa stimulasi listrik dapat dilaksanakan pada karkas sapi dewasa yang memberikan hasil memperbaiki mutu daging, menguragi kolagen daging dan meningkatkan keempukan.

Swatland (1984) menyatakan bahwa resistensi karkas terhadap perlakuan stimulasi listrik dipengaruhi oleh beberapa faktor sebagai berikut; (1) tenggang waktu antara pemotongan ternak dengan stimulasi listrik, (2) jarak antara elektroda, (3) kontak area permukaan elektroda dengan daging, (4) ukuran karkas, apakah karkas utuh, belahan karkas atau potongan karkas, (5) lokasi stimulasi listrik, (6) lama waktu dan voltase stimulasi listrik.

Penelitian bertujuan untuk mengetahui pengaruh lama stimulasi listrik dan jenis otot terhadap kandungan air, $\mathrm{pH}$ dan cooking loss daging sapi Pesisir dan melihat kualitas daging sapi Pesisir yang terbaik yang dihasilkan oleh perlakuan stimulasi listrik

\section{Materi Dan Metode}

Dalam penelitian ini digunakan daging sapi Pesisir jantan umur sekitar 2 tahun yang dipotong di Rumah Potong Hewan Kota Padang. Pengambilan sampel daging dilakukan pada bagian otot Longissimus dorsi, Supra spinatus dan Bicep femoris.

Alat yang digunakan dalam penelitian, antara lain: timbangan sapi, seperangkat alat abatoir, timbangan karkas, alat stimulasi listrik yang mempunyai tegangan 220 volt dan peralatan analisis air, $\mathrm{pH}$ dan cooking loss daging.

Penelitian ini dirancang menurut pola percobaan faktorial $3 \times 3$ dengan dasar Rancangan Acak Kelompok, dengan 3 kelompok (ulangan). Faktor A adalah lama waktu dilaksanakan stimulasi listrik, dimana terdiri dari 3 taraf yaitu $\mathrm{A} 1=1$ menit, $\mathrm{A} 2=2$ menit dan $\mathrm{A} 3=3$ menit. Sedangkan faktor $\mathrm{B}$ adalah jenis otot daging yaitu $\mathrm{B} 1=$ Otot Longissimus dorsi, B2 = Otot Supra spinatus dan B3 $=$ Otot Biceps 
femoris. Sebagai kelompok adalah hari pengambilan sampel.

Model statistik yang digunakan adalah model linear (Steel dan Torrie, 1980), yaitu :

$$
\begin{aligned}
& Y(i j k)=\mu+k i+\alpha j+\beta k+(\alpha \beta) j k+ \\
& \text { Eijk, }
\end{aligned}
$$

dimana:

$$
\begin{aligned}
\mathrm{Y}(\mathrm{ijk})= & \text { nilai pengamatan pada } \\
& \text { perlakuan } \mathrm{i} \text { dan } \mathrm{j}, \mathrm{ke}- \\
& \text { lompok ke } \mathrm{k} \\
\mu & \text { nilai tengah umum } \\
\mathrm{Ki}= & \text { pengaruh kelompok yang } \\
& \text { ke- } \mathrm{i} \\
\alpha \mathrm{j}= & \text { pengaruh taraf ke-j dari } \\
& \text { perlakuan } \mathrm{A} \\
\beta \mathrm{k}= & \text { pengaruh taraf ke-k } \\
& \text { perlakuan } \mathrm{B} \\
(\alpha \beta) \mathrm{jk}= & \text { pengaruh interaksi taraf } \\
& \text { ke-j perlakuan A dan } \\
& \text { taraf ke-k perlakuan } \mathrm{B} \\
\text { Eijk }= & \text { pengaruh sisa }
\end{aligned}
$$

Peubah yang diamati adalah kandungan air, $\mathrm{pH}$ dan cooking loss daging sapi Pesisir.

\section{Kandungan Air}

Kandungan air ditentukan menurut metode Buckle et al. (1985) yaitu dengan pemanasan sample dalam oven selama 11 jam pada suhu $105^{\circ} \mathrm{C}$, kemudian dimasukkan dalam eksikator selama 1 jam, lalu ditimbang sampai beratnya tetap.

Perhitungan:

Kadar air $=\frac{a-b}{c} \times 100 \%$

Keterangan :

$$
\begin{aligned}
\mathrm{a}= & \text { berat cawan }+ \text { berat sampel } \\
\mathrm{b}= & \text { berat cawan }+ \text { berat sampel } \\
& \text { setelah dikeringkan } \\
\mathrm{c}= & \text { berat sampel }
\end{aligned}
$$

\section{pH Daging}

Sampel daging sebanyak $10 \mathrm{~g}$, diiris kecil - kecil dan dicacah sampai halus. Selanjutnya dimasukkan ke dalam beker glas $50 \mathrm{ml}$, diencerkan dengan dengan aquades sebanyak 10 $\mathrm{ml}$ diaduk sampai homogen dan $\mathrm{pH}$ (derajat keasaman) diukur dengan $\mathrm{pH}$ meter (Ngadiono, 1995).

\section{Cooking Loss}

Timbang sampel daging seberat $100 \mathrm{gr}$, lalu rebus selama lebih kurang 1 jam pada temperatur 80 oC. Bilas dengan kertas tissu lalu ditimbang kembali. Hitung selisih antara berat sebelum dimasak dengan sesudah dimasak. Kemudian hasil ini dipresentasekan terhadap berat sebelum dimasak.

\section{Tempat Penelitian}

Penelitian ini dilaksanakan dalam dua tahap, yaitu (a) tahap pemotongan (penyembelihan), dan (b) tahap evaluasi daging. Tahap pemotongan dilaksanakan di Rumah Potong Hewan (RPH) Kota Padang dan tahap evaluasi daging dilaksanakan di Laboratorium Ternak Potong \& Kerja Fakultas Peternakan.

\section{Hasil Dan Pembahasan}

\section{Kandungan Air}

Kandungan air daging sapi Pesisir yang distimulasi listrik dengan tegangan 220 volt dengan waktu yang berbeda pada berbagai jenis otot dapat dilihat pada Tabel 1.

Dari hasil analisis keragaman diketahui bahwa tidak terdapat pengaruh interaksi antara lama stimulasi listrik dengan jenis otot sapi Pesisir $(P>0,05)$ terhadap kandungan air daging. Begitu juga pengaruh 
masing - masing faktor (lama stimulasi listrik dan jenis otot) terhadap kandungan air tidak memperlihatkan pengaruh yang nyata. Kandungan air daging sapi Pesisir ternyata tidak dipengaruhi oleh lama stimulasi listrik, berarti ransangan stimulasi listrik selama 1,2 dan 3 menit memberikan pengaruh yang sama terhadap daya ikat air daging. Rataan kandungan air daging sapi Pesisir hasil penelitian adalah antara $76,55-78,17 \%$. Hasil ini lebih tinggi dari penelitian Parakkasi (1985), dimana kadar air karkas tanpa lemak dari berbagai jenis spesies berkisar antara $71-73 \%$. Tingginya kandungan air daging sapi Pesisir erat hubungannya dengan kandungan lemaknya yang rendah. Biasanya kandungan air daging berbanding terbalik dengan kandungan lemaknya.
Menurut Minish dan Fox (1979) kandungan lemak daging mempunyai korelasi negatif dengan kandungan air daging, sehingga semakin tinggi kadar lemak daging akan semakin rendah kandungan air daging.

Air di dalam urat daging dibagi tiga lapisan, yaitu air yang terikat secara kimiawi oleh protein daging sebesar $4-5 \%$ sebagai lapisan mono molekuler pertama, air terikat agak lemah sebagai lapisan kedua dari molekul air terhadap grup reaktif protein, sebesar kira - kira $4 \%$. Air lapisan kedua ini biasanya disebut air imobilisasi (tidak bergerak). Lapisan ketiga adalah molekul - molekul air bebas diantara molekul protein, berjumlah kira - kira 20 - $60 \%$ (Wismer, 1971).

Tabel 1. Rataan Kandungan Air Daging Sapi Pesisir yang Distimulasi Listrik dengan Waktu yang Berbeda pada Berbagai Jenis Otot (\%)

\begin{tabular}{ccccc}
\hline \multirow{2}{*}{$\begin{array}{c}\text { Lama SL } \\
\text { (Faktor A) }\end{array}$} & \multicolumn{3}{c}{ Jenis Otot (Faktor A) } & \multirow{2}{*}{ Rataan } \\
\cline { 2 - 4 } & LD & SS & BF & \\
\hline 1 menit & 78,17 & 76,75 & 76,71 & 77,21 \\
2 menit & 76,55 & 75,84 & 77,35 & 76,58 \\
3 menit & 77,10 & 76,91 & 77,41 & 77,11 \\
Rataan & 77,24 & 76,50 & 77,16 & 76,97 \\
\hline
\end{tabular}

Tabel 2. Rataan Nilai pH Daging Sapi Pesisir yang Distimulasi Listrik dengan Waktu yang Berbeda pada Berbagai Jenis Otot

\begin{tabular}{ccccc}
\hline \multirow{2}{*}{$\begin{array}{c}\text { Lama SL } \\
\text { (Faktor A) }\end{array}$} & \multicolumn{3}{c}{ Jenis Otot (Faktor A) } & \multirow{2}{*}{ Rataan } \\
\cline { 2 - 4 } & LD & SS & BI & \\
\hline 1 menit & 6,03 & 6,00 & 5,89 & $5,96^{\mathrm{a}}$ \\
2 menit & 5,63 & 5,74 & 5,64 & $5,67^{\mathrm{ab}}$ \\
3 menit & 5,73 & 5,39 & 5,70 & $5,61^{\mathrm{b}}$ \\
Rataan & 5,80 & 5,74 & 5,70 & 5,74 \\
\hline Keterangan : Superskrip & yang berbeda pada baris yang sama menunjukkan berbeda Nyata \\
& & & &
\end{tabular}




\section{pH Daging}

Nilai $\mathrm{pH}$ daging sapi Pesisir yang distimulasi listrik dengan waktu 1 menit, 2 menit dan 3 menit pada otot longissimus dorsi, supra spinatus dan bicep femoris dapat dilihat pada Tabel 2. Dari hasil analisis ketagantun diketahui bahwa tidak terdapat pengaruh interaksi antara lama waktu stimulasi listrik dengan jenis otot sapi Pesisir $(\mathrm{P}>0,05)$ terhadap nilai $\mathrm{pH}$ daging sapi Pesisir. Begitu juga pengaruh jenis otot tidak berpengaruh nyata terhadap nilai $\mathrm{pH} \quad(\mathrm{P}>0,05)$. Sedangkan lama waktu stimulasi listrik berpengaruh nyata terhadap nilai $\mathrm{pH}$ daging sapi $\mathrm{Pesisir}(\mathrm{P}<0,05)$.

Semakin lama waktu stimulasi listrik nilai $\mathrm{pH}$ daging semakin rendah, hal ini berarti semakin lama waktu stimulasi listrik semakin banyak terjadinya perombakan glikogen menjadi asam laktat. Rataan nilai $\mathrm{pH}$ daging daging yang distimulasi listrik selama 1 menit, 2 menit dan 3 menit berturut - turut adalah 5,96; 5,67 dan 5,61.

Hasil uji statistik memperlihatkan bahwa nilai $\mathrm{pH}$ daging yang distimulasi listrik selama 1 menit tidak berbeda nyata dengan yang distimulasi listrik 2 menit, tetapi berbeda nyata dengan nilai $\mathrm{pH}$ daging yang distimulasi listrik selama 3 menit. Sedangkan $\mathrm{pH}$ daging yang distimulasi listrik selama 2 menit tidak berbeda nyata dengan $\mathrm{pH}$ daging yang distimulasi listrik selama 3 menit.

Stimulasi listrik akan dapat mempercepat penurunan $\mathrm{pH}$, karena stimulasi listrik akan mempercepat terjadinya glikolisis, sehingga penimbunan asam laktat akan lebih banyak. Penimbunan asam laktat yang tinggi akan menyebabkan terjadinya penurunan $\mathrm{pH}$ daging. Hal ini sesuai dengan pendapat McCollum dan Henrickson (1977) bahwa stimulasi listrik akan mempercepat proses glikolisis postmortem, sehingga akan mempercepat habisnya ATP dan penurunan $\mathrm{pH}$ daging. Pendapat Ressang (1061) hahiva pll daging sesaat dipotong adalah 7, lalu menurun dengan adanya asam laktat hasil perombakan glikogen pada saat terjadinya glikolisis, sampai suatu saat glikogen habis dan $\mathrm{pH}$ terendah 5,4.

\section{Cooking Loss}

Nilai cooking loss daging sapi Pesisir yang distimulasi listrik dengan waktu 1 menit, 2 menit dan 3 menit pada otot longissimus dorsi, supra spinatus dan bicep femoris dapat dilihat pada Tabel 3.

Dari hasil analisis keragaman diketahui bahwa tidak terdapat pengaruh interaksi antara lama waktu stimulasi listrik dengan jenis otot sapi Pesisir $(\mathrm{P}>0,05)$ terhadap nilai cooking loss daging sapi Pesisir. Begitu juga pengaruh lama waktu stimulasi listrik tidak berpengaruh nyata terhadap nilai cooking losss $(\mathrm{P}>0,05)$. Sedangkan jenis otot berpengaruh nyata terhadap nilai cooking loss daging sapi Pesisir. Dari hasil uji statistik diketahui bahwa otot longissimus dorsi cooking lossnya berbeda nyata dengan nilai cooking loss otot supra spinatus dan otot bicep femoris, sedangkan otot supra spinatus nilai cooking losnya tidak berbeda nyata dengan otot bicep femoris, dimana nilai coking loss otot longissimus dorsi, supra spinatus dan bicep femoris berturut - turut adalah $41,04 \%$, 38,09 \% dan 38,69\%. Menurut Soeparno (1992) jenis otot mempengaruhi kualitas otot terutama keempukannya, dimana semakin tidak 
Tabel 3. Rataan Nilai Cooking loss Daging Sapi Pesisir yang Distimulasi Listrik dengan Waktu yang Berbeda pada Berbagai Jenis Otot (\%)

\begin{tabular}{|c|c|c|c|c|}
\hline \multirow{2}{*}{$\begin{array}{c}\text { Lama SL } \\
\text { (Faktor A) }\end{array}$} & \multicolumn{3}{|c|}{ Jenis Otot (Faktor A) } & \multirow{2}{*}{ Rataan } \\
\hline & LD & SS & $\mathrm{BF}$ & \\
\hline 1 menit & 42,31 & 38,99 & 39,50 & 40,27 \\
\hline 2 menit & 40,51 & 38,14 & 38,62 & 39,09 \\
\hline 3 menit & 40,30 & 37,14 & 37,96 & 38,46 \\
\hline Rataan & $41,04^{\mathrm{a}}$ & $38,09^{b}$ & $38,69^{b}$ & 39,27 \\
\hline
\end{tabular}

aktif otot tersebut seratnya semakin halus dan otot yang mempunyai serat yang halus lebih empuk. Namun demikian semakin empuk daging tersebut maka susut masaknya semakin tinggi.

Untuk itu dianjurkan pada daging yang mempunyai serat yang halus tidap perlu membutuhkan waktu yang lama. Hal ini juga disebabkan karena pada otot yang mempunyai serat daging yang halus gugus protein yang mengikat airnya akan mudah menjadi rusak, sehingga waktu pemasakan lebih banyak air yang keluar.

Rataan nilai cooking loss atau susut masak selama penelitian berkisar antara $37,14-42,31 \%$. Nilai tersebut hampir sama yang didapatkan oleh Lawrie (1985) yaitu 40,5 \%. Hasil penelitian Bouton et al. (1978) menyatakan susut masak menurun secara linear dengan hertambahnya umur ternak. Misalnya pada sapi, susut masak otot SM yang dimasak pada temperatur $80{ }^{\circ} \mathrm{C}$ selama 90 menit, menurun dengan meningkatnya umur. Umur 2, 9, 16, 27, 42 dan 120 bulan, susut masak masing-masing adalah 34,$5 ; 33,3 ; 33,6 ; 32,3 ; 32,5$ dan $31,3 \%$. Perbedaan nilai tersebut kemungkinan disebabkan oleh banyak hal, seperti materi yang digunakan dalam penelitian, waktu pengambilan data, jenis otot yang digunakan, besar potongan daging contoh, teknis perebusan dan lain sebagainya.

\section{Kesimpulan}

Dari hasil penelitian ini dapat disimpulkan bahwa tidak terdapat interaksi $(P>0,05)$ antara lama waktu stimulasi listrik dan jenis otot terhadap kandungan air, $\mathrm{pH}$ dan cooking loss daging sapi Pesisir. Lama waktu stimulasi listrik berpengaruh nyata $(\mathrm{P}$ $<0,05$ ) terhadap $\mathrm{pH}$ daging dan tidak berpengaruh nyata terhadap kandungan air dan cooking loss daging. Jenis otot berpengaruh nyata $(\mathrm{P}<$ $0,05)$ terhadap cooking loss dan tidak berpengaruh nyata terhadap kandungan air dan nilai $\mathrm{pH}$ daging.

\section{Daftar Pustaka}

Bouton, P.E., A.L. Ford, P.V. Harris dan F.D. Shaw. 1978. Effect of low voltage stimulation of beef carcasses on muscle tenderness and $\mathrm{pH}$. J. Fd. Sci. 43:13921396.

Edwards, R.L., S.B. Tove, T.N. Blumer dan E.R. Barrick. 1961. 
Effects of added dietary fat on fatty acid composition and carcass characteristics of fattening steers. J. Anim. Sci. 20:712-717.

Forrest, G.J., Aberle, H.B. Hendrick, M.D. Judge dan R.A. Merkel. 1975. Principles of Meat Science. W.H. Freeman and Company, San Francisco.

Gurnadi, E. 1993. Peranan PMA dan PMDN dalam Memenuhi Permintaan Daging Sapi Kualitas Ekspor. Lokakarya Strategi Operasional Investasi dan Perdagangan Agro-Industri Sapi Potong, Jakarta.

Khasrad. 1998. Pengaruh Stimulasi Listrik Terhadap Keempukan dan Uji Organoleptik Sapi Pesisir. Fakultas Peternakan Universitas Andalas.

Lawrie, R.A. 1974. Meat Science. 4 th. ed. Pergamon Press, OxfordNew York.

McCollum, P.D. dan R.L. Henrickson. 1977. In Animal Science Research Report. Editor R.H. Thayer dan J.R. Cozart. Oklahoma State University dan USDA.

McKeit, F.K., G.C. Smith, J.W. Savell, T.R. Dutson, Z.L. Carpenter dan D.R. Hammons. 1980. Electrical stimulation of mature cow carcasses. J. Anim. Sci. 50:694-698.
Minish, G.L. dan D.G. Fox. 1979. Beef Production and Management. Reston Publishing Co, Inc, A Prentice Hall Co., Reston. Virginia.

Natasasmita, A. 1978. Body composition of swamp buffalo (Bubalus bubalis), a study of development growth and sex differences. Ph.D. Thesis. University of Melbourne.

Parakkasi, A. 1985. Ilmu Nutrisi dan Makanan Ternak. Vol. 2 B. Fakultas Peternakan IPB, Bogor.

Ressang. 1961. Ilmu Kesehatan Daging. Fakultas Kesehatan Hewan, Institut Pertanian Bogor, Bogor.

Soeparno. 1992. Ilmu dan Teknologi Daging. Gajah Mada University Press. Yogyakarta.

Steel, R.G.D. dan J.H. Torrie. 1980. Prinsip dan Prosedur Statistika. Suatu Pendekatan Biometrik, Gramedia Pustaka Utama, Jakarta.

Swatland, H.J. 1984. Strukture and Development of Meat Animals. Prentice-Hall, Inc., Englewood Cliffs, New Jersey.

Wismer, P.J. 1971. Chemistry of animal tissues: Water. Dalam: Science of Meat and Meat products, 2 nd ed. J. F. Price dan B.S. Schweigert (Eds). W.H. Freeman and Co., San Francisco, Hal. 177-207.

Alamat korespondensi: Hilda Susanti, S.Pt

Jurusan Produksi Ternak Fakultas Peternakan

Universitas Andalas, Kampus Limau Manis

Padang

Diterima: 1 Januari 2007, Disetujui: 30 Januari 2007 